\title{
Pengaruh Faktor Sikap, Norma Subjektif, Demografi, Sosioekonomi serta Literasi Keuangan Syariah dan Konvensional terhadap Minat Berwirausaha pada Mahasiswa
}

\section{The Influence of Attitude, Subjective Norm, Demography, Sosioeconomic and Shariah and Conventional Financial Literacy Toward Entrepreneurship Intention Among College Students}

\section{Fajar Adi ${ }^{1}$, Ujang Sumarwan ${ }^{2}$ \& Idqan Fahmi ${ }^{3}$}

\author{
${ }^{1}$ Program Magister Manajemen Syariah pada Sekolah Bisnis Institut Pertanian Bogor, E-mail: \\ fajar.adi01@gmail.com \\ ${ }^{2}$ Departemen Ilmu Konsumen dan Keluarga, Fakultas Ekologi Manusia, Institut Pertanian Bogor, \\ E-mail: sumarwan@apps.ipb.ac.id \\ ${ }^{3}$ Departemen Ilmu Ekonomi, Fakultas Ekonomi dan Manajemen, Institut Pertanian Bogor, E-mail : \\ ifahmi.mk@gmail.com
}

\begin{abstract}
This cross sectional study aimed to analyse influence of attitude, subjective norm, demography, sosioeconomic and shariah and conventional financial literacy toward entrepreneurship intention among college students. Refers to the model of Theory of Reasoned Action developed by Fishbein dan Ajzen, behavioral intentions are a function of attitude toward behavior and the subjective norm (Sumarwan 2011). Respondents were 100 college students selected by convenience sampling methods. Data collection was purposively conducted at public universities located in Jakarta, Bogor, Depok and Tangerang on February 2016 until August 2016. Interview was conducted using reliable and valid questionnaire as a tool. Descriptive analysis on attitude toward entrepreneurship showed that respondents strongly agreed with the attitude statement and subjective norm indicates that they disagree with recommendation from nearest person to start a business. In addition, analysis of the entrepreneurship intention showed that respondents have an interest to become entrepreneur. Regression analysis with dummy variable showed that entrepreneurship intention was significantly affected by variables of attitude toward entrepreneurship and conventional financial literacy ( $p$ value $<0.05$ ), gender (women tend to be more interested in entrepreneurship as compared to men), experience of taking entrepreneurship class and experience of being entrepreneur ( $p$ value $<0.10$ ). To increase student's entrepreneurship intention, it needs efforts from various parties, especially from academics to build attitude toward entrepreneurship and to increase financial literacy among students.
\end{abstract}

Keywords: attitude, entrepreneurship, financial literacy, intention, subjective norm.

\begin{abstract}
Abstrak. Penelitian desain survei cross sectional ini bertujuan untuk menganalisis pengaruh faktor sikap, norma subjektif, demografi, sosioekonomi serta literasi keuangan syariah dan konvensional terhadap minat berwirausaha pada mahasiswa. Mengacu pada Model Teori Sikap Beralasan yang dikembangkan oleh Fishbein dan Ajzen, minat perilaku dipengaruhi oleh sikap terhadap perilaku dan norma subjektif (Sumarwan 2011). Teknik pengambilan sampel yang digunakan adalah convenience sampling dengan jumlah responden sebanyak 100 orang. Lokasi penelitian ini ditentukan secara sengaja (purposive) yaitu di Jakarta, Bogor, Depok, dan Tangerang, dan dilaksanakan pada bulan Februari 2016 hingga Agustus 2016. Pengumpulan data dilakukan melalui tatap muka langsung menggunakan kuesioner yang reliabel dan valid. Analisis deskriptif pada sikap terhadap wirausaha menunjukkan hasil bahwa mayoritas reponden menyatakan setuju, sedangkan pada norma subjektif menunjukkan hasil bahwa tidak setuju terhadap anjuran orang terdekat untuk memulai sebuah usaha. Analisis terhadap minat berwirausaha, menunjukkan hasil bahwa responden memiliki minat untuk menjadi wirausahawan. Analisis regresi dengan variabel dummy menunjukkan hasil bahwa minat berwirausaha secara signifikan dipengaruhi oleh sikap terhadap wirausaha, literasi keuangan konvensional ( $p$ value <0.05), jenis kelamin (wanita cenderung lebih berminat pada
\end{abstract}


dibandingkan pria), pengalaman mengikuti kuliah kewirausahaan dan pengalaman berwirausaha ( $p$ value $<0.10$ ). Untuk meningkatkan minat berwirausaha pada mahasiswa, diperlukan dukungan dari berbagai pihak, khususnya dari akademisi untuk membangun sikap terhadap wirausaha dan untuk meningkatkan literasi keuangan pada mahasiswa.

Kata kunci: literasi keuangan, minat, norma subjektif, sikap, wirausaha.

\section{Pendahuluan}

\subsection{Latar Belakang}

Salah satu persoalan mendasar yang dihadapi Indonesia adalah rendahnya jumlah wirausahawan baru. Rendahnya jumlah wirausahawan baru akan berdampak terhadap lambatnya perluasan kesempatan kerja, yang pada akhirnya akan meningkatkan jumlah pengangguran (Wuryandani 2014). Menurut Yohnson (2003), peranan universitas dalam memotivasi lulusannya menjadi wirausahawan muda sangat penting dalam menumbuhkan jumlah wirausahawan. Sayangnya, minat berwirausaha pada lulusan perguruan tinggi di Indonesia masih sangat rendah yaitu 2,74\% (Wahyuningsih 2009).

Berdasarkan beberapa penelitian, diketahui bahwa minat berwirausaha dipengaruhi oleh sejumlah faktor, diantaranya yaitu faktor sikap terhadap minat berwirausaha dan faktor norma subjektif (Linan et al. 2011; Van Galderen et al. 2006); faktor demografi, yang terdiri dari jenis kelamin (Verheul et al. 2011), mayor pendidikan atau bidang pendidikan (Hein 2011) dan tingkat pendidikan (Thung 2014); serta, faktor sosioekonomi keluarga yaitu tipe pekerjaan orang tua (Thung 2014). Roxas et al. (2008) menjelaskan bahwa pengetahuan berwirausaha (salah satunya pengetahuan keuangan) berpengaruh terhadap minat berwirausaha. Namun, penelitian yang menganalisis adanya pengaruh tingkat literasi keuangan terhadap minat berwirausaha pada mahasiswa masih sangat sedikit. Menurut Oseifuah (2010) literasi keuangan berkontribusi terhadap kemampuan berwirausaha. Agustianto (2015) menyatakan bahwa pembangunan literasi keuangan syariah di Indonesia sebagai negara dengan penduduk mayoritas Muslim adalah sebuah keniscayaan, karena potensi keuangan syariah di Indonesia masih sangat besar, sementara tingkat literasi masih rendah.

Mengacu pada literasi keuangan syariah, Febianto (2010) menyatakan bahwa dalam setiap kegiatan proses manajemen bisnis, salah satunya manajemen keuangan, ada beberapa aspek syariah yang harus diperhatikan dan harus mengikuti aturan syariah yang disebut Fiqh Muamalah. Lebih lanjut Febianto (2010) menyebutkan bahwa Fiqh Muamalah adalah hukum Islam yang mengatur hubungan antara manusia dan manusia dan semua tindakan mereka dan interkoneksi (kegiatan apa pun diizinkan kecuali ada ketentuan yang melarangnya). Khan dalam P3EI UII (2013) menyatakan bahwa bisnis yang didirikan sesuai syar'i bertujuan untuk mencapai Falah sebagai tujuan hidup setiap insan Muslim. Sehingga dalam berbagai aktivitas pengelolaan bisnis secara Syariah tidak hanya memandang aspek materil, namun justru lebih ditekankan pada aspek spiritual. Muhammad (2009) menyimpulkan bahwa nilai fundamental dalam bisnis yang sering terabaikan adalah nilai spiritual. Lantaran pelaku bisnis terjebak pada adigium, bahwa wilayah bisnis dan agama adalah wilayah yang berbeda.

Kehadiran lembaga jasa keuangan syariah telah menarik perhatian masyarakat Indonesia yang mayoritas beragama Islam. Upaya memperkenalkan layanan keuangan syariah telah dilakukan oleh bank-bank syariah melalui berbagai kegiatan di tempat-tempat publik, termasuk di sekolah dan perguruan tinggi (Bisnis.com 2015). Menurut PP No.4/2014, perguruan tinggi terdiri dari perguruan tinggi negeri (PTN) dan perguruan tinggi swasta 
(PTS). Standar mutu lulusan PTN yang dijamin oleh pemerintah sebagai penyelenggara, menjadikan mahasiswa PTN tepat sebagai objek penelitian ini. Di Jakarta, Bogor, Tangerang dan Depok terdapat tiga perguruan tinggi negeri yang merupakan PTN unggulan di Indonesia, yaitu Universitas Indonesia (UI), Institut Pertanian Bogor (IPB) dan Univesitas Islam Negeri (UIN) Syarif Hidayatullah.

Martani (1999) menyatakan bahwa di perguruan tinggi (PT), mahasiswa mendapatkan pendidikan baik dari segi kecerdasan, keterampilan maupun mental, yang menjadikan mahasiswa sebagai penggerak pembangunan yang produktif, maka penelitian tentang minat berwirausaha dan faktor-faktor yang memengaruhinya sangat tepat dilakukan pada mahasiswa. Selain itu, mengingat pentingnya tingkat literasi keuangan, baik konvensional maupun syariah, maka penelitian tingkat literasi keuangan juga tepat dilakukan di kalangan mahasiswa, karena pengetahuan keuangan akan sangat berguna ketika mereka lulus, mulai bekerja dan memperoleh pendapatan.

Namun, diketahui bahwa terdapat celah penelitian (research gap) yaitu belum adanya penelitian yang berusaha menganalisis pengaruh tingkat literasi keuangan konvensional maupun syariah, terhadap minat berwirausaha pada mahasiswa. Oleh karena itu, penelitian mengenai faktor-faktor yang memengaruhi minat berwirausaha pada mahasiswa, dengan tingkat literasi keuangan konvensional maupun syariah sebagai salah faktor yang memengaruhinya, sangat penting untuk dilakukan.

\subsection{Perumusan Masalah}

Masalah pengangguran menjadi masalah klasik bangsa ini, dimana saat ini jumlah pengangguran bukan hanya karena disebabkan oleh kurangnya pendidikan yang diterima, namun lulusan perguruan tinggi juga memberi sumbangan terhadap jumlah total pengangguran di Indonesia. Pentingnya kewirausahaan diharapkan tidak hanya mampu memanfaatkan keberadaan sumber daya yang ada, namun juga mampu memberikan nilai tambah (value added) bagi masyarakat dan lingkungan. Menurut Geoffrey et al. (2005), para wirausaha adalah orang-orang yang mempunyai kemampuan melihat dan menilai kesempatan-kesempatan bisnis, mengumpulkan sumberdaya yang dibutuhkan guna mengambil tindakan yang tepat guna memastikan sukses. Oleh karena itu, dengan mengetahui minat berwirausaha dikalangan generasi muda, khususnya mahasiswa, diharapkan dapat meningkat jumlah wirausahawan dimasa yang akan datang.

Berdasarkan berbagai uraian diatas, perlu dilakukan kajian tentang bagaimana tingkat minat berwirausaha pada mahasiswa. Selain itu, perlu dilakukan kajian tentang faktorfaktor apa saja yang mempengaruhi minat berwirausaha pada mahasiswa. Sehingga penelitian ini diharapkan mampu menjawab permasalahan sebagai berikut:

1. Bagaimana tingkat minat berwirausaha pada mahasiswa?

2. Apa faktor-faktor yang memengaruhi minat berwirausaha pada mahasiswa?

3. Seberapa besar pengaruh sikap terhadap wirausaha, norma subjektif, demografi dan sosioekonomi keluarga serta tingkat literasi keuangan konvensional dan syariah terhadap minat berwirausaha pada mahasiswa?

\subsection{Tujuan Penelitian}

Tujuan dari penelitian ini adalah sebagai berikut:

1. Menganalisis minat berwirausaha pada mahasiswa.

2. Menganalisis faktor-faktor yang memengaruhi minat berwirausaha pada mahasiswa. 
3. Mengukur pengaruh sikap terhadap wirausaha, norma subjektif, demografi dan sosioekonomi, serta tingkat literasi keuangan konvensional dan syariah terhadap minat berwirausaha pada mahasiswa.

\section{Tinjauan Pustaka}

\subsection{Kerangka Teoritis}

\subsubsection{Minat Berwirausaha}

Menurut Wijaya (2008), minat adalah kesungguhan niat dari seseorang untuk melakukan perbuatan atau memunculkan suatu perilaku tertentu. Wirausahawan adalah individuindividu yang berorientasi pada tindakan, dan bermotivasi tinggi yang mengambil risiko dalam mengejar tujuannya. Sifat-sifat yang dimiliki oleh wirausahawan diantaranya yaitu percaya diri, berorientasikan tugas dan hasil, berani mengambil risiko, memiliki jiwa kepemimpinan, dan berorientasi ke masa depan (Geoffrey et al. 2005). Ramayah dan Harun (2005) mengatakan bahwa minat berwirausaha diukur dengan skala entrepreneural intention menggunakan indikator memilih jalur usaha daripada bekerja pada orang lain, memilih karir sebagai wirausaha, dan membuat perencanaan untuk memulai usaha.

Menurut Indarti dan Rostiani (2008), proses perkembangan perekonomian bertumpu pada munculnya usaha-usaha baru perorangan dan dimulai dalam skala kecil. Kelebihan usaha baru dalam skala kecil yaitu rendahnya hambatan masuk, dilihat dari investasi modal, kompetensi dan informasi yang dibutuhkan, sehingga minat berwirausaha pada mahasiswa di Indonesia lebih baik dibanding dengan negara yang hambatan masuknya lebih tinggi, seperti Jepang.

\subsubsection{Sikap dan Norma Subjektif}

Sumarwan (2000), menyatakan bahwa sikap seseorang terhadap suatu objek ditentukan oleh sikapnya terhadap berbagai atribut yang dimiliki objek tersebut. Robbins (2006) menyatakan sikap merupakan pernyataan evaluatif - baik disukai atau tidak disukai tentang suatu objek, orang, atau kejadian -kejadian. Menurut Sumarwan (2011), Karakteristik sikap diantaranya yaitu: sikap memiliki objek; konsistensi sikap; sikap positif, negatif dan netral; intensitas sikap; resitensi sikap; persistensi sikap; dan keyakinan sikap.

Model sikap multiatribut Fishbein merupakan pengukuran sikap yang paling populer yang digunakan oleh para peneliti. Model ini terdiri atas tiga model: (a) The attitude-towardobject model, digunakan untuk mengukur sikap konsumen terhadap suatu produk (pelayanan/jasa) atau berbagai merek produk; (b) The attitude-toward-behaviour model; dan (c) The theory of reasoned-action model (Sumarwan 2011).

Fishbein dan Ajzen dalam Blue (1995), menyatakan bahwa menurut Theory of Reasoned Action (TRA), niat perilaku (behavioral intention), adalah prediktor tunggal terbaik dari perilaku (behavior) seseorang. Niat perilaku merupakan fungsi dari sikap terhadap perilaku (attitude toward behavior) dan norma subjektif (subjective norm), dalam diagram dapat dilihat pada Gambar 1. 


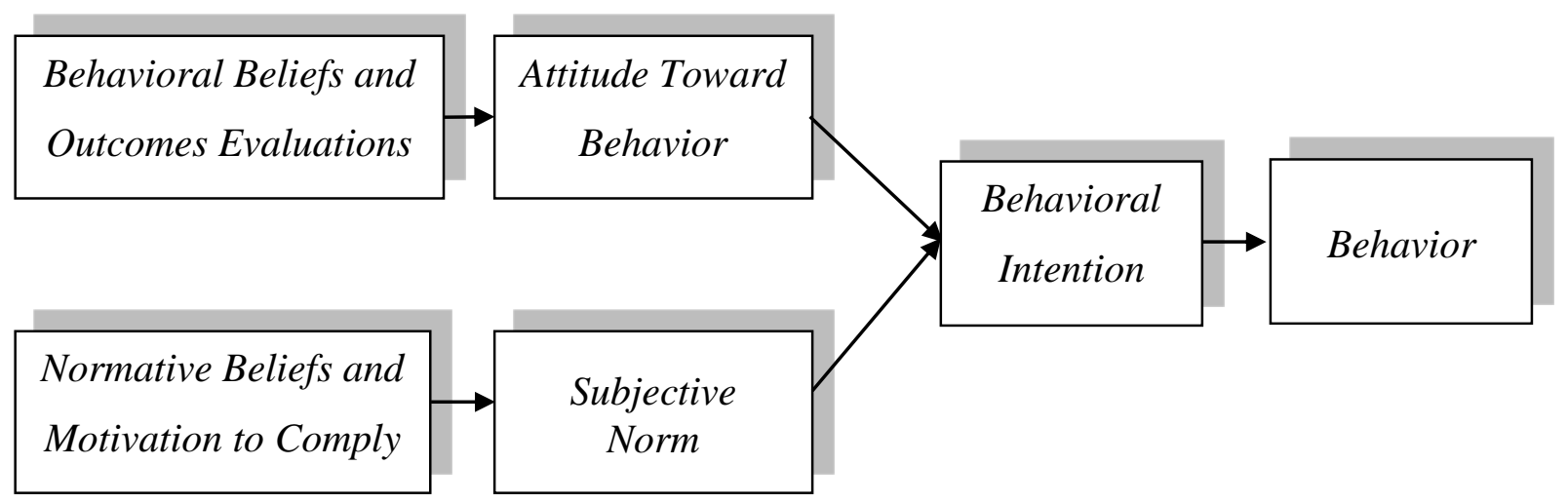

(Sumber: Blue 1995 p.106)

\section{Gambar 1 Theory of Reasoned Action}

Teori Sikap Beralasan (Theory of Reasoned Action atau Fishbein's Behavioral Intentions Model) secara matematis dapat dijelaskan dengan formula sebagai berikut (Sumarwan 2011):

$$
\mathbf{B} \sim \mathrm{BI}=\mathrm{W}_{1}\left(\mathrm{~A}_{\mathrm{B}}\right)+\mathrm{W}_{2}(\mathrm{SN})
$$

\section{Dimana:}

$\mathrm{B}=$ = Perilaku atau tindakan yang sesungguhnya yang diduga sama dengan kecenderungan melakukan tindakan tersebut BI

$\mathrm{BI}=$ Kecenderungan melakukan perilaku atau tindakan tertentu

$\mathrm{A}_{\mathrm{B}} \quad=$ Sikap terhadap melakukan perilaku atau tindakan tertentu

$\mathrm{SN} \quad=$ Norma subjektif mengenai perilaku tertentu

$\mathrm{W}_{1}, \mathrm{~W}_{2}$, = Bobot yang menggambarkan pengaruh relatif $\mathrm{AB}$ dan $\mathrm{SN}$ Terhadap kecenderungan melakukan perilaku tertentu

\subsubsection{Demografi}

Demografi berasal dari bahasa Yunani yang merupakan gabungan dua kata, yaitu demos dan grafein yang artinya rakyat dan tulisan. Jadi demografi adalah setiap tulisan atau gambaran tentang rakyat atau penduduk. Istilah tersebut pertama kali digunakan oleh Achille Guillard pada tahun 1885 (Iskandar 1994). Definisi demografi kemudian berkembang seiring dengan perkembangan zaman serta kebutuhan kependudukan.

Konsep subbudaya sangat terkait dengan demografi. Demografi akan menggambarkan karakteristik suatu penduduk. Di dalam variabel demografi tersebut akan diketahui subbudaya yang berbeda (Sumarwan 2011). Saat ini, demografi merupakan bagian yang penting dalam perilaku konsumen, karena merupakan informasi yang mudah dijangkau dan relatif lebih murah untuk mengidentifikasikan segmentasi pasar (Kasali 2005). 


\subsubsection{Sosioekonomi Keluarga}

Status sosioekonomi adalah gambaran tentang keadaan seseorang atau suatu masyarakat yang ditinjau dari segi sosial ekonomi, gambaran itu seperti tingkat pendidikan, pendapatan dan sebagainya (Soetjiningsih dalam Suparyanto 2010). Menurut Friedman dalam Suparyanto (2010), indikator yang dapat membentuk status sosioekonomi seseorang adalah pendidikan, pekerjaan, keadaan ekonomi, latar belakang budaya, dan pendapatan. Sedangkan keluarga adalah sebuah kelompok yang terdiri atas dua orang atau lebih yang terikat oleh perkawinan, darah (keturunan: anak atau cucu) dan adopsi (Sumarwan 2011).

Variabel pekerjaan orang tua sebagai entrepreneur berpengaruh secara signifikan dan positif terhadap probabilitas seorang anak menjadi entrepreneur. Hal ini mengindikasikan terjadinya mekanisme transmisi kewirausahaan dari orang tua kepada anak-anak mereka (Thung 2014). Wulandari (2013) dalam penelitiannya meyimpulkan bahwa status sosioekonomi orang tua berpengaruh terhadap minat berwirausaha, dimana status sosioekonomi mengacu kepada beberapa kriteria yaitu ukuran ilmu pengetahuan, ukuran kekuasaan, ukuran kehormatan, dan ukuran kekayaan.

\subsubsection{Tingkat Literasi Keuangan}

Literasi keuangan telah didefinisikan pada beberapa sumber, namun demikian, tidak ada sebuah konsesus tentang definisi literasi keuangan, hal tersebut didasari karena luasnya definisi dari literasi keuangan (Abdullah \& Chong 2014). Secara umum definisi literasi keuangan yaitu kemampuan seseorang mengenai keuangan, memproses informasi keuangan dan membuat keputusan keuangan berdasarkan informasi yang diperoleh (Atkinson dan Messy 2010; Cole dan Fernando 2008; Mason dan Wilson 2000).

Berbeda dengan literasi keuangan secara umum (keuangan konvensional), definisi literasi keuangan syariah masih sangat terbatas. Isnurhadi (2013), menyebutkan definisi literasi keuangan syariah adalah kesadaran, pengetahuan, sikap, tingkah laku dalam membuat keputusan-keputusan berkaitan dengan aktivitas perbankan seseorang yang dalam hal ini spesifik perbankan syariah atau dengan kata lain pengetahuan yang dimiliki seseorang tentang perbankan syariah.

Istilah "Syariah" dalam definisi literasi keuangan Syariah, digunakan untuk menunjukkan penggunaan sistem Islami dalam melakukan aktivitas ekonomi. Pemberian label "Syariah" pada suatu entitas bisnis, bukan hanya sekedar klaim pihak pengelola semata, karena "Syariah" oleh para ahli hukum Islam, diartikan sebagai "seperangkat peraturan atau ketentuan dari Allah untuk manusia yang disampaikan melalui Rasul-Nya" (Al-Sahdili dalam P3EI UII 2013).

\subsection{Kajian Penelitian Terdahulu}

\subsubsection{Pengaruh Sikap Terhadap Minat Berwirausaha}

Sah (2013) dalam penelitiannya mengenai hubungan sikap dan personality dengan entrepreneurial intention di kalangan mahasiswa, menyebutkan bahwa terdapat hubungan antara attitudes dengan entrepreneurial intention. Dengan teknik analisis data yang digunakan adalah spearman correlation. Penelitian terkait sikap terhadap wirausaha juga pernah dilakukan oleh Andika dan Madjid (2012) dengan menggunakan Theory of Planned Behavior menyimpulkan bahwa terdapat pengaruh sikap terhadap minat berwirausaha pada mahasiswa, dengan teknik analisis data yang digunakan adalah analisis regresi berganda. 
Penelitian lainnya terkait pengaruh sikap terhadap wirausaha dilakukan oleh Linan et al. (2011) dalam penelitiannya menggunakan instrument Entrepreneural Intention Question (EIQ) menyimpulkan bahwa personal attitude dan perceived behavioural control merupakan faktor yang paling relevan yang dapat menjelaskan minat berwirausaha. Hein (2011) dalam hasil penelitannya menunjukkan bahwa mahasiswa yang memiliki sikap terhadap wirausaha yang positif maka akan memiliki minat berwirausaha yang lebih tinggi dibandingkan dengan mahasiswa dengan sikap yang negatif. Senada dengan Hein (2011), penelitian yang dilakukan oleh Wijaya (2008), dengan teknik analisis data menggunakan Structural Equation Model (SEM) juga menyimpulkan bahwa sikap terhadap wirausaha yang positif berpengaruh positif terhadap minat berwirausaha pada pelaku UKM di DIY dan Jawa Tengah.

Berdasarkan berbagai hasil penelitian tentang minat berwirausaha pada mahasiswa, diketahui bahwa minat berwirausaha dipengaruhi oleh faktor sikap, yaitu semakin positif sikap terhadap wirausaha, maka semakin tinggi minat berwirausaha pada mahasiswa (Sah 2013; Andika dan Madjid 2012; Linan et al. 2011; Hein 2011; Wijaya 2008).

\subsubsection{Pengaruh Norma Subjektif Terhadap Minat Berwirausaha}

Koranti (2013) melakukan penelitian dengan tujuan untuk menganalisis pengaruh faktor eksternal dan faktor internal terhadap minat berwirausaha pada mahasiswa, dengan menggunakan analisis regresi berganda, Koranti (2013) menyimpulkan bahwa faktor lingkungan keluarga dan lingkungan sekitar mahasiswa terbukti berpengaruh signifikan terhadap minat berwirausaha pada mahasiswa. Penelitian lainnya terkait pengaruh norma subjektif terhadap minat berwirausaha adalah penelitian yang dilakukan oleh Sarwoko (2011), dengan menggunakan teknik analisis regresi berganda, disimpulkan bahwa norma subjektif dan efikasi diri (self efficacy) berpengaruh positif terhadap minat berwirausaha mahasiswa.

Roxas et al. (2008) dalam penelitiannya yang bertujuan untuk merumuskan kerangka konseptual minat berwirausaha, menyimpulkan bahwa dukungan norma subjektif mempengaruhi minat berwirausaha pada mahasiswa. Sejalan dengan pendapat tersebut, Wijaya (2008) juga menyimpulkan bahwa terdapat pengaruh yang positif dari norma subjektif terhadap minat berwirausaha.

Berdasarkan berbagai hasil penelitian menyimpulkan pengaruh yang ditunjukkan norma subjektif terhadap minat berwirausaha adalah bersifat positif, yaitu semakin baik dukungan norma subjektif maka akan semakin tinggi minat berwirausaha pada mahasiswa (Koranti 2013; Sarwoko 2011; Roxas et al. 2008; Wijaya 2008).

\subsubsection{Pengaruh Demografi Terhadap Minat Berwirausaha}

Ismawati (2014) dalam penelitiannya yang bertujuan menganalisis pengaruh jender terhadap minat berwirausaha menyimpulkan bahwa terdapat perbedaan signifikan minat berwirausaha antara pria dan wanita, dimana wanita memiliki kecenderungan memiliki minat berwirausaha yang lebih rendah daripada pria. Senada dengan pendapat Ismawati (2014), penelitian yang dilakukan oleh Verheul et.al. (2011) menunjukkan hasil bahwa wanita memiliki preferensi yang lebih kecil dalam berwirausaha, sehingga dapat dikatakan bahwa jender dapat saja menjadi hambatan dalam berwirausaha. Penelitian yang dilakukan oleh Sarwoko (2011) juga menunjukkan hasil yang sama bahwa mahasiswa pria memiliki minat berwirausaha lebih tinggi dibandingkan dengan mahasiswa wanita. Wang dan Wong (2004) juga mengungkapkan bahwa terdapat pengaruh signifikan dari jender terhadap minat berwirausaha pada mahasiswa di Singapura. 
Penelitian lainnya yang mengungkapkan adanya pengaruh demografi yaitu usia terhadap minat berwirausaha pada mahasiswa dilakukan oleh Muhar (2013). Menurut Muhar (2013) mahasiswa yang berusia muda memiliki intensi kewirausahaan yang lebih tinggi dibandingkan dengan mahasiswa yang berusia tua. Hal ini disebabkan adanya faktor kebutuhan atau pandangan kedepan setelah mahasiswa menyelesaikan studinya. Bagi mahasiswa yang berusia muda, relatif belum memikirkan masalah peluang kerja, sedangkan mereka yang berusia tua telah memasuki usia yang dituntut untuk berfikir setelah mereka menamatkan masa studinya.

Lebih lanjut Muhar (2013) mengungkapkan bahwa mahasiswa dengan mayor pendidikan ekonomi dan bisnis memiliki intensi kewirausahaan yang lebih tinggi dibanding mereka yang memiliki mayor pendidikan non ekonomi dan bisnis. Turker dan Selcuk (2009) dalam penelitiannya yang menggunakan Entreprenurial Support Model (ESM) menggunakan fungsi educational, relational dan structural support untuk mengetahui minat berwirausaha. Hasil penelitian Turker dan Selcuk (2009) menyatakan bahwa educational yang terdiri dari tingkat pendidikan dan tipe pendidikan dan structural support mempengaruhi minat berwirausaha pada mahasiswa. Senada dengan pendapat tersebut, Thung (2014) menyimpulkan bahwa tingkat pendidikan berpengaruh secara signifikan tetapi bernilai negatif.

Berdasarkan berbagai uraian tentang kajian penelitian terdahulu, diketahui bahwa faktor demografi dapat memengaruhi minat berwirausaha, yang terdiri dari jenis kelamin, wanita memiliki kecenderungan minat berwirausaha yang lebih rendah daripada pria, dan pengalaman membantu bisnis keluarga (Ismawati 2014; Verheul et al. 2011; Sarwoko 2011; Wang dan Wong 2004); usia (Muhar 2013); mayor dan tingkat pendidikan (Turker $\&$ Selcuk 2009; Thung 2014; Muhar 2013).

\subsubsection{Pengaruh Sosioekonomi Keluarga Terhadap Minat Berwirausaha}

Minat berwirausaha juga dapat diprediksi berdasarkan faktor sosioekonomi keluarga, diantaranya yaitu tipe pekerjaan orang tua, status pekerjaan orang tua dan tingkat pendapatan orang tua. Tipe pekerjaan orang tua sebagai entrepreneur berpengaruh terhadap minat untuk menjadi seorang entrepreneur (Thung 2014). Mopangga (2014) menyimpulkan bahwa rendahnya minat berwirausaha dipengaruhi oleh rendahnya dukungan orang tua yang berprofesi sebagai pegawai. Menurut Wulandari et al. (2013), status pekerjaan orang tua dan tingkat pendapatan orang tua, juga diketahui memiliki pengaruh terhadap minat berwirausaha.

\subsubsection{Pengaruh Tingkat Literasi Keuangan Terhadap Minat Berwirausaha}

Literatur yang menunjukkan adanya pengaruh tingkat literasi keuangan terhadap minat berwirausaha sangat terbatas. Oseifuah (2010) menemukan bahwa tingkat literasi keuangan di kalangan wirausahawan muda berada di atas rata-rata dan tingkat literasi keuangan berkontribusi terhadap kemampuan berwirausaha. Indarti dan Kristiansen (2003) serta Indarti dan Rostiani (2008) menyimpulkan bahwa akses kepada modal berpengaruh terhadap minat berwirausaha pada mahasiswa.

Roxas et al. (2008) menyatakan pengetahuan berwirausaha, dimana salah satunya yaitu pemahaman (literasi) terhadap manajemen keuangan, berpengaruh terhadap minat berwirausaha pada mahasiswa. Wise (2013) menjelaskan bahwa semakin baik tingkat literasi keuangan pada wirausahawan yang baru memulai usahanya, maka semakin besar peluang usaha tersebut dapat bertahan (survive). 


\subsection{Kerangka Pemikiran Penelitian}

Dalam mencapai tujuan penelitian untuk menganalisis minat berwirausaha pada mahasiswa dan faktor-faktor yang memengaruhinya, berdasarkan penelitian terdahulu, digunakan Theory of Reasoned Action yang terdiri dari faktor sikap terhadap wirausaha dan norma subjektif sebagai faktor-faktor yang memengaruhi minat berwirausaha pada mahasiswa. Juga diketahui bahwa faktor demografi dan faktor sosioekonomi keluarga serta faktor tingkat literasi keuangan konvensional maupun syariah juga berpengaruh terhadap minat berwirausaha pada mahasiswa.

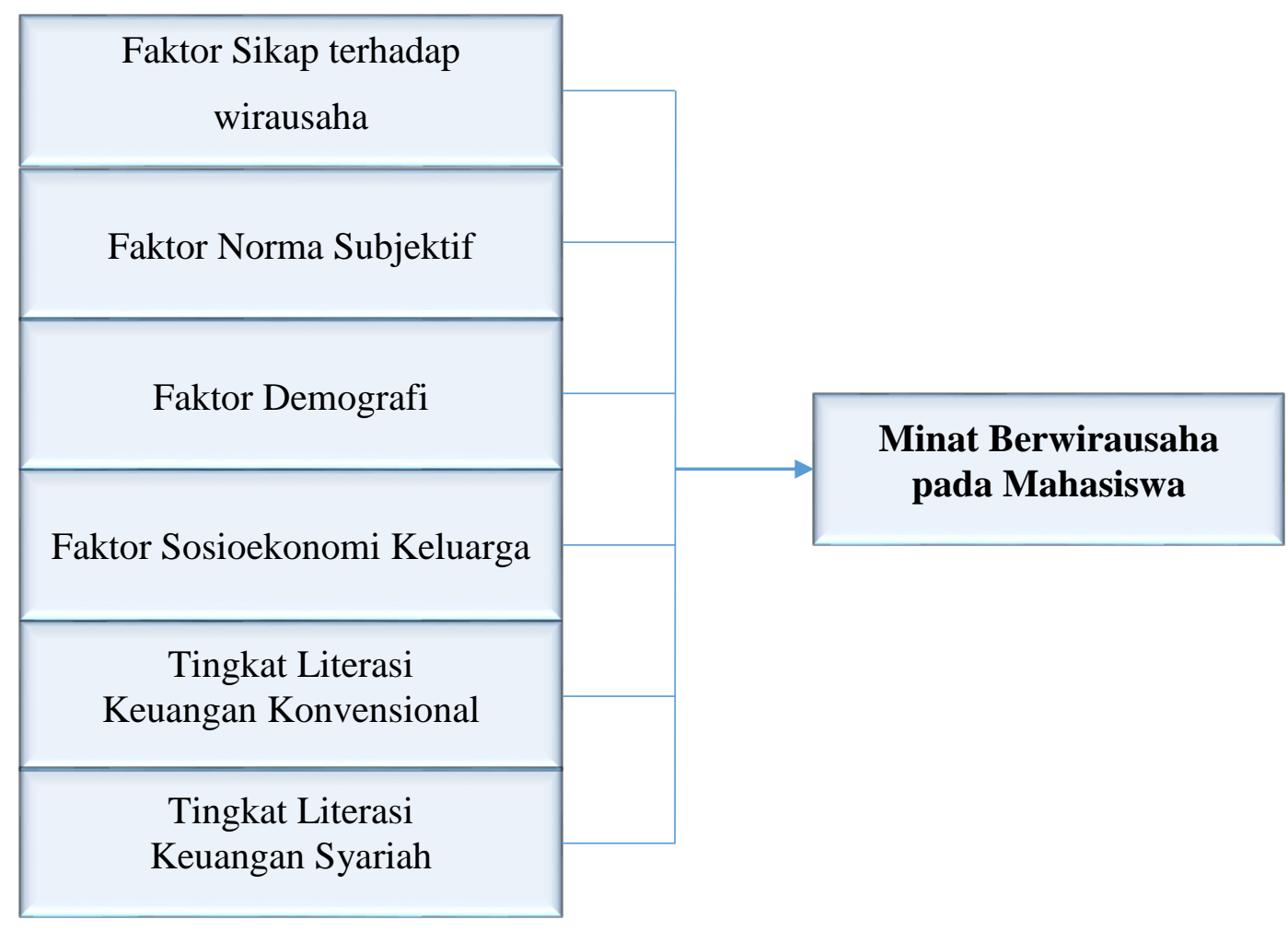

\section{Gambar 2 Kerangka Pemikiran Penelitian}

\section{Metode Penelitian}

\subsection{Lokasi dan Waktu Penelitian}

Penelitian ini dilakukan di Jakarta, Bogor, Depok, dan Tangerang. Lokasi penelitian tersebut ditentukan secara sengaja (purposive), dengan pertimbangan bahwa di daerahdaerah tersebut terdapat perguruan tinggi negeri. Adapun waktu penelitian adalah pada bulan Februari 2016 hingga Agustus 2016.

\subsection{Desain Penelitian}

Penelitian ini menggunakan desain survei, dengan horison waktu satu kali dalam satu periode (cross sectional studies). Penelitian ini termasuk penelitian deskriptif, dimana penelitian deskriptif merupakan tipe riset konklusif. Menurut Cooper dan Schindler (2008) tipe riset konklusif bertujuan untuk mendeskripsikan karakteristik suatu populasi dan mengetahui hubungan antara variabel yang berbeda. Pada penelitian ini, data primer diperoleh melalui instrumen kuesioner. Pengumpulan data dilakukan melalui pengisian 
kuesioner dengan tatap muka langsung. Dilakukan pretesting pada tiga puluh responden. Data sekunder diperoleh dari hasil riset kepustakaan berupa penelitian terdahulu, bukubuku yang terkait, jurnal dan informasi valid dari internet.

\subsection{Teknik Pengambilan Sampel}

Unit contoh (sampling unit) yang tersedia untuk dipilih adalah semua mahasiswa pada perguruan tinggi negeri (PTN) di Jakarta, Depok, Bogor, dan Tangerang, yaitu Universitas Indonesia, Institut Pertanian Bogor dan UIN Syarif Hidayatullah. Fraenkel dan Wallen (2009) menyarankan besar sampel minimum untuk penelitian deskriptif sebanyak 100, sehingga jumlah sampel penelitian ini adalah 100 orang. Teknik pengambilan sampel dalam penelitian ini adalah non-probability sampling, dengan teknik sampling yang digunakan adalah convenience sampling.

\subsection{Deskripsi Variabel dan Pengukuran}

\subsubsection{Variabel Dependen}

Variabel dependen atau variabel terikat yang digunakan dalam penelitian ini adalah minat berwirausaha. Dalam beberapa penelitian, variabel minat dijelaskan oleh satu indikator. Namun dalam penelitian ini, minat berwirausaha diukur dengan skala minat berwirausaha yang dikembangkan berdasarkan berdasarkan instrumen yang dibangun oleh Ramayah dan Harun (2005), yaitu berniat, berfikir, berencana, akan menjadi dan memilih menjadi seorang wirausahawan. Kontruksi pernyataan pembangun komponen sikap terhadap wirausaha dapat dilihat pada Tabel 1.

Tabel 1 Kontruksi pernyataan pembangun minat berwirausaha

\begin{tabular}{|c|c|}
\hline No & Pernyataan \\
\hline 1 & Saya berniat untuk menjadi seorang wirausahawan \\
\hline 2 & Saya berfikir bahwa saya akan mencoba untuk menjadi seorang wirausahawan \\
\hline 3 & $\begin{array}{l}\text { Saya berencana untuk menjadi seorang wirausahawan bila tidak mendapatkan } \\
\text { pekerjaan }\end{array}$ \\
\hline 4 & $\begin{array}{l}\text { Saya akan menjadi seorang wirausahawan meskipun tidak diajarkan } \\
\text { bagaimana cara menjalankan bisnis }\end{array}$ \\
\hline 5 & $\begin{array}{l}\text { Saya telah memilih untuk menjadi seorang wirausahawan walaupun belum } \\
\text { lulus kuliah }\end{array}$ \\
\hline
\end{tabular}

\subsubsection{Variabel Independen}

Variabel independen yang digunakan dalam penelitian ini adalah:

1. Sikap terhadap wirausaha (attitude toward behaviour)

Sikap terhadap perilaku (attitude toward behaviour component) dapat dijelaskan dengan dua komponen pembentuk variable sikap terhadap wirausaha (Sumarwan 2011), dapat dijelaskan dengan persamaan $\sum \mathbf{b}_{\mathbf{i}} \mathbf{e}_{\mathbf{i}}$ dimana;

$b_{i}$ : Kepercayaan melakukan perilaku yang berakibat konsekuensi ke i.

$e_{i}$ : Evaluasi terhadap konsekuensi ke i

2. Norma subjektif

Sumarwan (2011) menjelaskan bahwa norma subjektif (Subjective norm component) dapat dijelaskan dengan menggunakan model persamaan $\sum \mathbf{b}_{\mathbf{k}} \mathbf{m}_{\mathbf{j}}$ dimana;

$b_{k}$ : Kepercayaan normatif untuk melakukan perilaku tertentu.

$m_{k}$ : Motivasi yang sejalan dengan kelompok acuan ke $\mathrm{k}$ 
3. Tingkat literasi keuangan konvensional dan syariah

Variabel tingkat literasi keuangan terdiri dari tingkat literasi keuangan konvensional dan tingkat literasi keuangan syariah, dimana masing-masing variabel diukur dengan menggunakan sepuluh indikator. Indikator yang digunakan untuk mengukur tingkat literasi keuangan konvensional dan syariah menekankan pada pertanyaan tentang pemahaman mengenai pengetahuan keuangan secara umum, pengetahuan tentang investasi, asuransi, tabungan dan kredit atau pembiayaan syariah.

4. Demografi dan sosioekonomi keluarga

Variabel demografi terdiri dari tujuh indikator variabel dummy dan satu indikator variabel kontinyu yaitu variabel usia. Variabel sosioekonomi keluarga terdiri dari dua indikator variabel dummy dan dirinci berdasarkan ayah dan ibu responden.

\subsection{Teknik Pengolahan dan Analisis Data}

\subsubsection{Uji Reliabilitas, Validitas dan Normalitas}

Reliabilitas bertujuan untuk mengukur konsistensi, suatu kostruk atau variabel dikatakan reliabel jika memiliki nilai Cronbach's Alpha lebih besar dari 0,600. Uji validitas dilakukan untuk mengetahui tingkat akurasi yang dicapai oleh sebuah indikator dalam menilai sesuatu. Uji validitas dapat dilakukan dengan Confirmatory Factor Analysis. Untuk uji normalitas dapat dilakukan dengan normal probability plot (Ghozali 2011).

\subsubsection{Analisis Regresi Dengan Variabel Dummy}

Menurut Ghozali (2011), permasalahan yang sering dihadapi pada regresi adalah adanya variabel independen yang berskala ukuran non-metrik atau kategori. Jika variabel independen berukuran kategori atau dikotomi, maka dalam model regresi variabel tersebut harus dinyatakan sebagai variabel dummy. Pada penelitian ini, terdapat dua variabel independen yang termasuk variabel dummy yaitu variabel demografi dan variabel sosioekonomi keluarga.

Menurut Ghozali (2011), untuk menjelaskan aplikasi dari variabel dummy, harus dilakukan transformasi menjadi bentuk logaritma natural (Ln) kecuali variabel dummy. Sehingga persamaan regresi penelitian ini adalah:

\section{B6Tkt}

Ln Mnb

(2)

dimana;

Mnb : Minat berwirausaha pada mahasiswa (indikator: berfikir, berencana, akan menjadi dan memilih menjadi seorang wirausahawan)

$\alpha \quad$ : Konstanta (intersep) dan $\beta_{1-16}$ : Koefisien (slop) variabel independen

Skp : Sikap terhadap wirausaha (diukur dengan indikator: bekerja dengan penuh kejujuran, giat dan tekun dalam bekerja, berani dalam menghadapi risiko, mencari informasi peluang usaha, dan tidak mudah menyerah)

Nor : Norma subjektif (diukur dengan indikator: keyakinan dukungan orang tua, saudara, teman, dosen, pengusaha)

Jkl : Jenis kelamin (variabel dummy diukur dengan menggunakan kode 1 untuk pria dan kode 0 untuk wanita.) 


\begin{tabular}{|c|c|}
\hline Usi & : Usia \\
\hline May & $\begin{array}{l}\text { Mayor perkuliahan (variabel dummy diukur dengan menggunakan kode } 1 \text { untuk } \\
\text { mayor ekonomi/manajemen/bisnis dan kode } 0 \text { untuk mayor non } \\
\text { ekonomi/manajemen/bisnis) }\end{array}$ \\
\hline Tkt & $\begin{array}{l}\text { : Tingkatan perkuliahan (variabel dummy diukur dengan menggunakan kode } 1 \\
\text { untuk Diploma, kode } 2 \text { untuk Sarjana dan kode } 3 \text { untuk Pascasarjana.) }\end{array}$ \\
\hline Org & $\begin{array}{l}\text { : Mengikuti organisasi kampus (variabel dummy diukur dengan menggunakan } \\
\text { kode } 1 \text { untuk mengikuti dan kode } 0 \text { untuk tidak mengikuti) }\end{array}$ \\
\hline $\mathrm{Pgl}$ & $\begin{array}{l}\text { : Pengalaman wirausaha (variabel dummy diukur dengan menggunakan kode } 1 \\
\text { untuk ada pengalaman dan kode } 0 \text { untuk tidak ada pengalaman) }\end{array}$ \\
\hline Kom & $\begin{array}{l}\text { : Pengalaman kompetisi wirausaha (variabel dummy diukur dengan } \\
\text { menggunakan kode } 1 \text { untuk mengikuti dan kode } 0 \text { untuk tidak mengikuti) }\end{array}$ \\
\hline Mkw & $\begin{array}{l}\text { : Mengikuti mata kuliah kewirausahaan (variabel dummy diukur dengan } \\
\text { menggunakan kode } 1 \text { untuk mengikuti dan kode } 0 \text { untuk tidak mengikuti) }\end{array}$ \\
\hline TipA & $\begin{array}{l}\text { : Tipe pekerjaan ayah (variabel dummy diukur dengan menggunakan kode } 1 \\
\text { untuk tidak bekerja, kode } 2 \text { untuk PNS, kode } 3 \text { untuk pegawai swasta, kode } 4 \\
\text { untuk TNI/Polri dan kode } 5 \text { untuk pengusaha) }\end{array}$ \\
\hline TipI & $\begin{array}{l}\text { Tipe pekerjaan ibu (variabel dumm diukur dengan menggunakan kode } 1 \text { untuk } \\
\text { tidak bekerja, kode } 2 \text { untuk PNS, kode } 3 \text { untuk pegawai swasta, kode } 4 \text { untuk } \\
\text { TNI/Polri dan kode } 5 \text { untuk pengusaha } y \text { ) }\end{array}$ \\
\hline PdkA & $\begin{array}{l}\text { : Pendidikan ayah (variabel dummy diukur dengan menggunakan kode } 1 \text { untuk } \\
\text { SD, kode } 2 \text { untuk SMP, kode } 3 \text { untuk SMA, dan kode } 4 \text { untuk perguruan tinggi) }\end{array}$ \\
\hline PdkI & $\begin{array}{l}\text { Pendidikan ibu (variabel dummy diukur dengan menggunakan kode } 1 \text { untuk SD, } \\
\text { kode } 2 \text { untuk SMP, kode } 3 \text { untuk SMA, dan kode } 4 \text { untuk perguruan tinggi) }\end{array}$ \\
\hline Lkk & $\begin{array}{l}\text { : Tingkat literasi keuangan konvensional (diukur dengan pertanyaan mengenai } \\
\text { pengetahuan keuangan secara umum, pengetahuan tentang investasi, asuransi, } \\
\text { tabungan dan kredit., dengan nilai skor: } 0-100 \text { ) }\end{array}$ \\
\hline Lks & $\begin{array}{l}\text { Tingkat literasi keuangan syariah (diukur dengan pertanyaan mengenai } \\
\text { pengetahuan umum keuangan syariah, serta pengetahuan investasi, asuransi, } \\
\text { tabungan, dan pembiayaan syariah, dengan nilai skor: } 0-100 \text { ) }\end{array}$ \\
\hline & Standard error (residual) \\
\hline
\end{tabular}

\section{Hasil dan Pembahasan}

\subsection{Profil Responden}

Proporsi jenis kelamin responden hampir sama antara lelaki (52\%) dan perempuan (48\%) dengan median usia 20 tahun. Sebagian besar responden merupakan mahasiswa sarjana (48\%) dengan major perkuliahan Ekonomi/Manajemen sebanyak 45\% dari total responden. Sebanyak $51 \%$ responden ikut serta dalam organisasi kemahasiswaan di kampusnya. Sebagian besar responden (71\%) pernah mendapatkan ilmu kewirausahaan, namun hanya $54 \%$ dari total responden saja yang memiliki pengalaman berwirausaha. Hanya $30 \%$ dari total responden saja yang memiliki pengalaman mengikuti kompetisi wirausaha.

Sebagian besar tingkat pendidikan orang tua responden sampai dengan tingkat perguruan tinggi (ayah sebesar 55\% dan ibu sebesar 59\%), sehingga bisa dikatakan bahwa keluarga responden memiliki kesadaran yang tinggi akan pentingnya pendidikan formal. Disamping itu, pekerjaan orang tua sebagai pengusaha dapat memberikan pengaruh kepada anak untuk menjadi pengusaha (Thung 2014). Pada penelitian ini, sebagian besar ayah $(41 \%)$ dan ibu $(40 \%)$ responden bekerja sebagai pegawai swasta, sedangkan hanya sedikit sekali ayah yang berprofesi sebagai pengusaha (8\%). 


\subsection{Minat Berwirausaha Pada Mahasiswa}

Minat berwirausaha pada mahasiswa dianalisis dengan memberikan lima pernyataan kepada responden (Tabel 2). Pada minat berwirausaha, diketahui bahwa mayoritas reponden menyatakan setuju, sebanyak lebih dari $50 \%$ reponden menyatakan setuju akan menjadi wirausahawan walaupun tidak diajarkan cara berwirausaha.

Tabel 2 Rekapitulasi tanggapan responden terhadap minat berwirausaha

\begin{tabular}{lccccc}
\hline Pernyataan & \multicolumn{5}{c}{ Respon (\%) } \\
\hline $\begin{array}{l}\text { Minat Berwirausaha } \\
\text { Saya berniat untuk menjadi seorang wirausahawan }\end{array}$ & 2 & 5 & 20 & 39 & 34 \\
$\begin{array}{l}\text { Saya berfikir bahwa saya akan mencoba untuk } \\
\text { menjadi seorang wirausahawan }\end{array}$ & 5 & 3 & 16 & 44 & 32 \\
$\begin{array}{l}\text { Saya berencana untuk menjadi seorang } \\
\text { wirausahawan bila tidak mendapatkan pekerjaan }\end{array}$ & 1 & 14 & 36 & 31 & 18 \\
$\begin{array}{l}\text { Saya akan menjadi seorang wirausahawan } \\
\text { meskipun tidak diajarkan bagaimana cara } \\
\text { menjalankan bisnis }\end{array}$ & 0 & 11 & 25 & 51 & 13 \\
$\begin{array}{l}\text { Saya telah memilih untuk menjadi seorang } \\
\text { wirausahawan walaupun belum lulus kuliah }\end{array}$ & 0 & 19 & 40 & 25 & 16 \\
\hline
\end{tabular}

\subsection{Perilaku Minat Berwirausaha Berdasarkan Sikap dan Norma Subjektif}

Variabel pembentuk minat berwirausaha berdasarkan Theory of Reasoned Action, yaitu sikap terhadap wirausaha dan norma subjektif (Sumarwan 2011). Pembentuk minat terhadap wirausaha ditujukkan pada Tabel 3.

Tabel 3 Komponen pembentuk minat berwirausaha

\begin{tabular}{ccccccc}
\hline \multirow{2}{*}{ No } & \multicolumn{3}{c}{ Sikap terhadap wirausaha } & \multicolumn{3}{c}{ Norma subjektif } \\
\cline { 2 - 7 } & $\mathrm{bb}_{\mathrm{i}}$ & $\mathrm{ebb}_{\mathrm{i}}$ & $\mathrm{b}_{\mathrm{i} \mathrm{x} \mathrm{e}_{\mathrm{i}}}$ & $\mathrm{mtc}_{\mathrm{i}}$ & $\mathrm{nb}_{\mathrm{i}}$ & $\mathrm{r}_{\mathrm{i}} \mathrm{x} \mathrm{m}_{\mathrm{i}}$ \\
\hline 1 & 4.58 & 4.51 & 20.66 & 3.38 & 3.32 & 11.22 \\
2 & 4.60 & 4.48 & 20.61 & 3.13 & 3.11 & 9.73 \\
3 & 4.41 & 4.30 & 18.96 & 3.13 & 3.35 & 10.49 \\
4 & 4.48 & 4.43 & 19.85 & 3.44 & 3.30 & 11.35 \\
5 & 4.61 & 4.54 & 20.93 & 3.54 & 3.55 & 12.57 \\
\hline Jumlah & \multicolumn{7}{c}{101.00} & & & 55.36 \\
\hline Rata-rata & 4.54 & 4.45 & 4.04 & 3.33 & 3.32 & 2.21 \\
\hline Kategori & \multicolumn{7}{c}{ Tinggi } & & & Rendah \\
\hline
\end{tabular}

Berdasarkan Tabel 3 diketahui bahwa komponen sikap terhadap wirausaha signifikan dalam membentuk minat berwirausaha (4.04). Sedangkan norma subjektif tergolong rendah dalam membentuk minat berwirausaha (2.21).

\subsection{Faktor-faktor yang Memengaruhi Minat Berwirausaha}

Rangkuman hasil output regresi, dimana variabel dependen yang digunakan adalah berfikir untuk menjadi seorang wirausahawan dapat dilihat pada Tabel 4. 
Tabel 4 Rangkuman hasil output regresi

\begin{tabular}{|c|c|c|c|}
\hline \multicolumn{4}{|c|}{ Variabel Dependen: Minat Berwirausaha (berfikir menjadi wirausahawan) } \\
\hline Variabel Independen & Koefisien & $t_{\text {hitung }}$ & Sig. \\
\hline Konstanta & -1.078 & -1.277 & .205 \\
\hline Sikap terhadap wirausaha & .402 & 11.232 & $.000^{1}$ \\
\hline Norma subjektif & 136 & 1.288 & .201 \\
\hline Usia & -.042 & -.192 & .848 \\
\hline Literasi keuangan konvensional & .263 & 2.413 & $.018^{1}$ \\
\hline Literasi keuangan Syariah & -.004 & -.041 & 968 \\
\hline Jenis kelamin & -.076 & -1.783 & $.078^{2}$ \\
\hline Tingkatan perkuliahan &.- & - & - \\
\hline Mayor perkuliahan & .079 & .979 & .330 \\
\hline Mengikuti organisasi kampus & .027 & .393 & 695 \\
\hline Mengikuti kuliah kewirausahaan & .115 & 1.970 & $.052^{2}$ \\
\hline Pengalaman wirausaha & .078 & 1.812 & $.074^{2}$ \\
\hline Pengalaman kompetisi wirausaha & .013 & 270 & .788 \\
\hline Pekerjaan ayah & -.038 & -1.629 & .107 \\
\hline Pendidikan ayah & -.053 & -1.506 & .136 \\
\hline Pekerjaan ibu & -.011 & -.426 & 672 \\
\hline Pendidikan ibu & -.034 & -.908 & .366 \\
\hline Koefisien determinansi $\left(\mathrm{R}^{2}\right)$ & $=0.756$ & & \\
\hline $\mathrm{F}_{\text {Hitung }}$ & $=17.305$ & & \\
\hline Sig. F & $=0.000$ & & \\
\hline$\sum_{N}$ Variabel Independen Signifikan & $\begin{array}{l}=5 \text { dari } 16 \\
=100\end{array}$ & & \\
\hline
\end{tabular}

Berdasarkan Tabel 4, maka persamaan regresi dinyatakan sebagai berikut:

$$
M n b=-1.078+0.402 S k p+0.263 L k k-0.076 J k l+0.115 M k w+0.078 P g l+\varepsilon
$$
Dimana:
Mnb : Minat berwirausaha pada mahasiswa
Skp : Sikap terhadap wirausaha
Lkk : Literasi keuangan konvensional
$J k l \quad:$ Jenis kelamin
$M k w \quad$ : Mengikuti kuliah kewirausahaan
$\mathrm{Pgl} \quad$ : Pengalaman berwirausaha

\subsubsection{Koefisien Determinasi}

Berdasarkan Tabel 4 di atas, diketahui bahwa besarnya koefisien determinasi atau $\mathrm{R}^{2}$ adalah sebesar 0,756 atau dapat dikatakan bahwa $75.6 \%$ variasi variabel minat berwirausaha (berfikir untuk menjadi seorang wirausahawan) diterangkan oleh variabel sikap, norma subjektif, literasi keuangan konvensional, literasi keuangan syariah, faktor demografi dan faktor sosioekonomi, sedangkan sisanya dipengaruhi oleh variabel-variabel lain diluar model.

\subsubsection{Uji F (Uji Signifikansi Simultan)}

Berdasarkan Tabel 4 diatas, diketahui bahwa secara keseluruhan model penelitian ini sudah baik karena nilai Uji F nya adalah signifikan ( $p$ value $<0.05$ ), yang artinya bahwa variabel sikap, norma subjektif, literasi keuangan konvensional, literasi keuangan syariah, faktor 
demografi dan faktor sosioekonomi secara serentak dan signifikan mempengaruhi variabel dependen minat berwirausaha (berfikir untuk menjadi wirausahawan).

\subsubsection{Uji t (Uji Signifikansi Parsial)}

Berdasarkan Tabel 4 di atas, diketahui bahwa secara parsial hanya ada 5 variabel independen dari 16 variabel yang secara signifikan mempengaruhi variabel dependen minat berwirausaha (berfikir untuk menjadi seorang wirausahawan). Variabel tersebut yaitu variabel sikap terhadap wirausaha, literasi keuangan konvensional, variabel jenis kelamin, variabel mengikuti kuliah kewirausahaan dan variabel pengalaman berwirausaha dengan nilai signifikansi masing-masing yaitu 0,000 dan 0.018 ( $p$ value $<0,05), 0.078,0.052$ dan 0.072 ( $p$ value $<0,10)$.

\subsection{Pembahasan}

Dari persamaan regresi, dapat diketahui bahwa dari semua variabel independen yang berpengaruh terhadap variabel dependen minat berwirausaha (berfikir untuk menjadi seorang wirausahawan), variabel sikap terhadap wirausaha memiliki pengaruh yang terbesar terhadap berfikir untuk menjadi seorang wirausahawan. Hal ini ditunjukkan oleh nilai koefisien regresi variabel sikap terhadap wirausaha sebesar 0,402. Nilai koefisien regresi yang bertanda positif pada variabel sikap terhadap wirausaha menunjukkan semakin positif sikap terhadap wirausaha maka akan semakin tinggi pula minat berwirausaha. Sikap diketahui memiliki pengaruh terhadap wirausaha menunjukkan bahwa penelitian yang telah dilakukan ini mendukung penelitian terdahulu yang dilakukan oleh Sah (2013), Andika dan Madjid (2012), Linan et al. (2011) Hein (2011), Wijaya (2008), Van Galderen et al. (2006) yang menyatakan bahwa minat berwirausaha dipengaruhi oleh faktor sikap, yaitu semakin positif sikap terhadap wirausaha, maka semakin tinggi minat berwirausaha pada mahasiswa.

Sedangkan variabel norma subjektif diketahui tidak memiliki pengaruh yang signifikan terhadap wirausaha. Hasil ini senada dengan penelitian yang telah dilakukan oleh Andika dan Madjid (2012) yang menyimpulkan bahwa variabel norma subjektif secara parsial tidak berpengaruh signifikan terhadap minat berwirausaha pada mahasiswa Fakultas Ekonomi Unsyiah. Hal ini mungkin disebabkan kurangnya dukungan orang tua terhadap minat berwirausaha pada mahasiswa. Pendapat peneliti tersebut diperkuat oleh pendapat Mopangga (2014) yang menyimpulkan bahwa rendahnya minat berwirausaha dipengaruhi oleh rendahnya dukungan orang tua yang berprofesi sebagai pegawai.

Oseifuah (2010), Indarti dan Kristiansen (2003) serta Indarti dan Rostiani (2008), Roxas et al. (2008) dan Wise (2013) menyatakan bahwa adanya pengaruh literasi keuangan terhadap minat berwirausaha. Hasil penelitian tersebut senada dengan hasil penelitian ini, bahwa ada pengaruh literasi keuangan konvensional terhadap minat berwirausaha. Hal ini menunjukkan bahwa semakin tinggi tingkat literasi keuangan konvensional, maka semakin tinggi minat berwirausaha pada mahasiswa.

Dalam literasi keuangan syariah, daftar hal-hal yang dilarang tidak terlalu panjang bila dibandingkan dengan daftar hal-hal yang diperbolehkan. Hanya ada tiga hal yang dalam praktik keuangan konvensional dianggap biasa, tetapi dalam literasi keuangan syariah dilarang, yaitu gharar, maisyir dan riba. Selain ketiga hal tersebut terdapat beberapa praktik dalam literasi keuangan konvensional yang juga terlarang dalam literasi keuangan syariah, seperti risywah atau suap, tadlis atau penipuan, dan juga praktik monopoli bisnis. Selain hal-hal yang dilarang tersebut semua jenis praktik keuangan diperbolehkan dalam Islam. Dari hasil penelitian menunjukkan bahwa tidak ada pengaruh dari literasi keuangan syariah 
terhadap minat berwirausaha. Hal ini mungkin disebabkan karena rendahnya tingkat literasi keuangan syariah.

Faktor lainya yang juga memiliki pengaruh terhadap minat berwirausaha yaitu faktor jenis kelamin. Hal ini menunjukkan bahwa, jenis kelamin merupakan faktor yang dapat memengaruhi minat berwirausaha pada mahasiswa. Namun hasil penelitian ini berbeda dengan hasil penelitian Ismawati (2014), Verheul et al. (2011), Sarwoko (2011), serta Wang dan Wong (2004) yang menyatakan bahwa wanita memiliki kecenderungan minat berwirausaha yang lebih rendah daripada pria, namun tetap mendukung hasil penelitian ini bahwa terdapat pengaruh jenis kelamin terhadap minat berwirausaha.

Hasil penelitian ini juga menunjukkan adanya pengaruh yang positif dari variabel pernah mengikuti kuliah kewirausahaan dan pernah mengikuti kompetisi kewirausahaan terhadap minat berwirausaha. Hal ini menunjukkan bahwa seseorang yang pernah mengikuti kuliah dan kompetisi kewirausahaan maka akan semakin tinggi minatnya untuk memulai sebuah usaha.

\subsection{Implikasi Manajerial}

Dari hasil penelitian ini diketahui bahwa, bekerja dengan penuh kejujuran, giat dan tekun dalam bekerja, berani dalam menghadapi risiko, mencari informasi peluang usaha dan tidak mudah menyerah merupakan indikator dari variabel sikap terhadap wirausaha yang mendukung minat berwirausaha pada mahasiswa. Oleh karena itu, sangat penting bagi pihak akademisi dan para orang tua agar dapat membangun sikap-sikap tersebut guna meningkatkan jumlah wirausahawan dimasa yang akan datang.

Tingkat literasi keuangan responden, baik literasi keuangan konvensional maupun syariah yang relatif rendah yaitu hanya 6 dan 5 (skala $0-10$ ), menunjukkan bahwa perlu upaya yang lebih signifikan dari para stakeholders guna meningkatkan literasi keuangan mahasiswa di masa yang akan datang. Hasil penelitian ini senada dengan hasil studi yang dilakukan oleh Otoritas Jasa Keuangan (OJK) pada tahun 2013 bahwa masyarakat Indonesia rata-rata memiliki indeks literasi keuangan yang relatif rendah yaitu 42,51 (skala 0 - 100). Oleh karena itu, diperlukan upaya peningkatan literasi keuangan baik konvensional maupun syariah melalui berbagai macam media, dan tidak hanya berfokus pada masyarakat yang berpendidikan tinggi, namun juga untuk masyarakat dengan pendidikan menengah atau sederajat.

Adanya pengaruh tingkat literasi keuangan terhadap minat berwirausaha perlu didukung oleh berbagai pihak, yaitu pihak akademisi dalam mengembangkan materi pendidikan literasi keuangan. Hal ini senada dengan pendapat Yohnson (2003) yang menyatakan bahwa perlu peranan perguruan tinggi dalam memotivasi lulusannya untuk menjadi wirausahawan, peranan perguruan tinggi yaitu melalui pemberian pendidikan kewirausahaan.

Selain pihak akademisi, juga diharapkan peranan pihak praktisi keuangan dan perbankan dalam menyediakan akses informasi dan akses finansial. Adanya literasi keuangan berbahasa arab pada literasi keuangan syariah menjadi tantangan bagi pihak praktisi keuangan dan perbankan syariah. Namun, hal tersebut bukan menjadi penghalang, karena pada prinsipnya literasi berbahasa arab sama halnya dengan literasi berbahasa asing lainnya dalam praktik keuangan konvensional.

Selain pihak akademisi dan praktisi, juga diperlukan adanya dorongan dari pihak pemerintah dalam menyediakan sarana dan prasarana pendukung dan penyediaan program 
peningkatan literasi keuangan, agar pengaruh literasi keuangan terhadap minat berwirausaha dapat menumbuhkan jumlah wirausahawan dimasa yang akan datang, dengan meningkatnya jumlah wirausahawan diharapkan akan mengurangi jumlah pengangguran, bahkan akan menambah atau membuka lapangan pekerjaan baru.

Adanya pengaruh jenis kelamin terhadap minat berwirausaha, khususnya pada wanita, menunjukkan bahwa diperlukan keterbukaan mindset bagi semua pihak bahwa saat ini tidak ada lagi persepsi perbedaan gender antara pria dan wanita dalam berperan sebagai wirausahawan. Minat berwirausaha diharapkan dapat menambah jumlah wirausahawan, oleh karena itu dengan adanya pengaruh jenis kelamin terhadap minat berwirausaha, diharapkan jumlah wirausahawan dari kalangan wanita semakin meningkat jumlahnya.

\section{Simpulan dan Saran}

\subsection{Simpulan}

1. Responden memiliki minat yang cukup baik untuk berwirausaha.

2. Faktor-faktor yang memengaruhi minat berwirausaha pada mahasiswa adalah sikap terhadap wirausaha, literasi keuangan konvensional, variabel jenis kelamin, variabel mengikuti kuliah kewirausahaan dan variabel pengalaman berwirausaha

3. Berdasarkan model regresi, variabel sikap terhadap wirausaha memiliki pengaruh yang terbesar terhadap minat berwirausaha.

\subsection{Saran}

1. Diperlukan dukungan dari berbagai pihak agar dapat lebih meningkatkan minat berwirausaha pada mahasiswa.

2. Diperlukan upaya yang lebih baik agar dapat membangun sikap terhadap wirausaha dan dapat meningkatkan literasi keuangan dikalangan mahasiswa pada khususnya dan masyarakat luas pada umumnya.

3. Diperlukan analisis lebih lanjut terhadap faktor-faktor lain yang berpengaruh terhadap minat berwirausaha, dan penelitian lebih mendalam mengenai responden dari kalangan lainnya selain mahasiswa.

\section{Daftar Pustaka}

Abdullah MA, Chong R. Financial Literacy: An Exploratory Review of The Literatur and Future Research. Journal of Emerging Economies and Islamic Research, 2(3), 1-9 (2014).

Agustianto. Strategi Nasional Literasi Keuangan Syariah Indonesia. [internet]. [diunduh 2015 Februari 10]. Tersedia pada: http://www.agustiantocentre.com/?p=1684 (2015).

Ajzen I. The Theory of Planned Behavior. Organizational Behavior and Human Decision Processes, 50, 179-211 (1991).

Ajzen I. Perceived Behavioral Control, Self-Efficacy, Locus of Control and Theory of Planned Behavior. Journal of Applied Social Psychology, 32, 665-683 (2002).

Andika M, Madjid I. Analisis Pengaruh Sikap, Norma Subjektif, dan Efikasi Diri Terhadap Intensi Berwirausaha Pada Mahasiswa (Studi Kasus Pada Mahasiswa FE Unsyiah). Eco-Entrepreneurship Seminar "Improving Performance by Improving Environment", pp. 190-197. Semarang: Fakultas Ekonomi Universitas Negeri Semarang (2012).

Atkinson A, Messy FA. Assessing Financial Literacy in 12 Countries: an OECD Pilot Exercise. Working Paper 115/11, pp. 1-32. Centre for Research on Pensions and Welfare Policies. Turin: CeRP (2010). 
Bisnis.com. Literasi Finansial: Keuangan Syariah Perlu Diajarkan Sejak SD. [internet]. syariah.bisnis.com: http://syariah.bisnis.com/read/20140915/232/257536/literasifinansial-keuangan-syariah-perlu-diajarkan-sejak-sd (10 Februari 2015).

Blue CL. The Predictive Capacity of The Theory Reasoned Action and The Theory of Planned Behavior in Exercise Research: An Integrated Literatur Review. Research in Nursing and Health, 18, 105-121 (1995).

Cole S, Fernando N. Assessing The Importance of Financial Literacy. ADB Finance for The Poor, A Quarterly Newsletter of The Focal Point for Microfinance, Vol 9(3). 1-8 (2008).

Cooper DR, Schindler PS. Business Research Methods 10th Edition. McGraw Hill. Jakarta: Penerbit PPM (2008).

Febianto, Irawan. Shariah Compliant Model of Business Entities. Faculty of Economic University of Padjadjaran. Bandung (2010).

Fraenkel JR, Wallen NE. How to Design and Evaluate Research in Education 7th edition. New York: McGraw-Hill (2009).

Geoffrey GM, Nelson RE, Neck PA. Kewirausahaan: Teori dan Praktek (2005).

Ghozali I. Aplikasi Analisis Multivariate dengan Aplikasi IBM SPSS 19. Semarang: Badan Penerbit Universitas Diponegoro (2011).

Hein B. Why Do Some Study Disciplines Produce More Entrepreneurs Than Others? Master Thesis, Maastricht University, Entrepreneurship and SME Management, Maastricht, Netherland (2011).

Hill RR, Perdue G. A Methodological Issue in The Measurement of Financial Literacy. Jurnal of Economics and Economics Education Research, 9(2), 43-59 (2008).

Indarti N. Factors Affecting Entreprenurial Intention Among Indonesian Students. Jurnal Ekonomi dan Bisnis, 19(1), 57-70 (2004).

Indarti N, Kristiansen S. Determinants of Entreprenuerial Intention. Gadjah Mada International Journal of Business, 5(1), 79-95 (2003).

Indarti N, Rostiani R. Intensi Kewirausahaan Mahasiswa: Studi Perbandingan antara Indonesia, Jepang dan Norwegia. Jurnal Ekonomika dan Bisnis Indonesia, 23(4), 1-9 (2008).

Iskandar N. Demografi: Arti dan Tujuan. Jakarta: Lembaga Demografi Fakultas Ekonomi Universitas Indonesia (1994).

Ismawati K. Analisis Pengaruh Perbedaan Jender Mahasiswa Ekonomi Akuntansi di Surakarta Terhadap Keinginan Wirausaha. Surakarta: Fakultas Ekonomi Universitas Surakarta, pp. 40-50 (2014).

Isnurhadi. Kajian Tingkat Literasi Masyarakat Terhadap Perbankan Syariah (Studi Kasus: Masyarakat Kota Palembang). Palembang: Program Studi Magister Manajemen Fakultas Ekonomi Universitas Sriwijaya (2013).

Kasali R. Membidik Pasar Indonesia (Segmentasi, Targeting, Positioning). Jakarta: Gramedia Pustaka Utama (2005).

Koranti K. Analisis Pengaruh Faktor Eksternal dan Internal Terhadap Minat Berwirausaha. Proceeding PESAT (Psikologi, Ekonomi, Sastra, Arsitektur, dan Teknik Sipil), pp. E1E8, 5 - Oktober 2013. Bandung: PESAT (2013).

Linan F, Cohard JR, Cantuche JR. Factor Affecting Entreprenurial Intention Levels. 45th Congress of The European Regional Science Association, 23-27 August 2005, pp. 1-18. Amsterdam (2005).

Martani MS. Peran Perguruan Tinggi Dalam Membentuk Pribadi Mahasiswa Yang Tangguh Untuk Mewujudkan Ketahanan Nasional. Tugas Akhir pada SUSPIM Lemhanas RI (1995).

Mason CL, Wilson RM. Conceptualising Financial Literacy. Occasional Paper, Loughborough Business School, Loughborough University (2000). 
Mopangga H. Faktor Determinan Minat Wirausaha Mahasiswa Fakultas Ekonomi dan Bisnis Universitas Negeri Gorontalo. Jurnal Trikonomika, 13(1), 78-90 (2014).

Muhammad. Label Halal dan Spiritualitas Bisnis : Interpretasi atas Bisnis Home Industry. Jornal Salam Volume 12 No. 2 (2009).

Muhar AM. Faktor Penentu Minat Berwirausaha di Kalangan Mahasiswa Perguruan Tinggi Negeri (Studi Perbandingan Mahasiswa USU, Unimed, dan IAIN). Jurnal Keuangan dan Bisnis, 5(1), 15-29 (2013).

Oseifuah EK. Financial Literacy and Youth Entrepreneurship in South Africa. African Journal of Economics and Management Studies, 1(2), 164-182 (2010).

Oseifuah EK, Gyekye AB. Analysis of the Level of Financial Literacy Among South African Undergraduates Students. Journal of Economics and Behavioral Studies, 6(3), 242-250 (2014).

Pusat Pengkajian dan Pengembangan Ekonomi Islam (P3EI) Universitas Islam Indonesia (UII) Yogyakarta. Ekonomi Islam. Raja Grafindo. Jakarta (2013).

Ramayah T, Harun Z. Entrepreneurial Intention Among The Students of Univesity Sains Malaysia (USM). International Journal of Management and Entrepreneurship, 1, 8-20 (2005).

Robbins SP. Orgaizational Behavior 12th Edition. Prentice Hall Inc (2006).

Roxas BG, Panizales RC, DeJesus, RM. Entrepreneurial Knowledge and Its Effect on Entrepreneurial Intention: Development of a Conceptual Framework. Asia Pacific Social Science Review, 8(2), 61-77 (2008).

Sah MP. Hubungan Antara Big Five Personality, Sikap, dan Entrepreneurial Intention di Kalangan Mahasiswa. Jurnal Ilmiah Universitas Surabaya, 2(2), 1-13 (2013).

Sarwoko E. Kajian Empiris Entrepreneur Intention Mahasiswa. Jurnal Ekonomi Bisnis, 16(2), 126-135 (2011).

Satrio YD. Analisis Financial Literacy Mahasiswa Fakultas Ekonomi Universitas Negeri Malang. Tesis, Program Pasca Sarjana Prodi S2 Pendidikan Ekonomi Fakultas Ekonomi Universitas Negeri Malang (2012).

Sumarwan U. Analisis Sikap Multiatribut Fishbein Terhadap Produk Biskuit Sandwich Coklat. Media Gizi dan Keluarga, 24(2), 79-85 (2000).

Sumarwan U. Perilaku Konsumen: Teori dan Penerapannya dalam Pemasaran Edisi 2. Bogor: Ghalia Indonesia (2011).

Suparyanto. Konsep Dasar Status Ekonomi. dr-suparyanto.blogspot.com: http://drsuparyanto.blogspot.com/2010/07/konsep-dasar-status-ekonomi.html $\quad(9$ Februari 2010).

Thung CE. Faktor Pro-Natal dan Post-Natal Sebagai Determinan Profesi Usaha: Studi Kasus di Indonesia. Jurnal AGORA, 2(1), 1-6 (2014).

Turker D, Selcuk SS. Which Factors Affect Entrepreneurial Intention of University Students. Journal of European Industrial Training, 33(2), 142-159 (2009).

Van Galderen M, Brand M, Van Praag M, Bodewes W, Poutsma E, Van Gils A. Explaining Entrepreneurial Intentions by Means of The Theory of Planned Behavior. Career Develpoment International, 13(6), 538-559 (2006).

Verheul I, Thurik R, Grilo I, Van Der Zwan P. Explaining Preference and Actual Involvement in Self-Employment: Gender and Entrepreneurial Personality . Journal of Economic Psychology, 1-17 (2011).

Wahyuningsih S. Peran UKM dalam Perekonomian Indonesia. Jurnal Mediagro, 9(1), 114 (2009).

Wang CK, Wong PK. Entrepreneurial Interst of University Student in Singapore. Technovation, 24, 163-172 (2004).

Wijaya T. Hubungan Adversity Intelligence dengan Intensi Berwirausaha. Jurnal Manajemen dan Kewirausahaan, 9(2), 117-127 (2007). 
Wijaya T. Kajian Model Empiris Perilaku Berwirausaha UKM DIY dan Jawa Tengah. Jurnal Manajemen dan Kewirausahaan, 10(2), 93-104 (2008).

Wise S. The Impact of Financial Literacy on New Venture Survival. International Journal of Business and Management, 8(23), 30-39 (2013).

Wulandari R, Asriati N, Warneri. Pengaruh Status Sosial Ekonomi Orang Tua Terhadap Minat Berwirausaha Pada Mahasiswa Program Studi Pendidikan Ekonomi. Pontianak: Pendidikan Ekonomi Universitas Tanjung Pura (2013).

Wuryandani D. Peluang dan Tantangan SDM Indonesia Menyongsong Era Masyarakat Ekonomi ASEAN. Info Ekonomi dan Kebijakan Publik P3DI, Vol VI. No. 17///P3DI/September/2014 (2014).

Yohnson. Peranan Universitas Dalam Memotivasi Sarjana Menjadi Young Entrepreneurs (Seri Penelitian Kewirausahaan). Jurnal Manajemen dan Kewirausahaan, 5(2), 97-111 (2003). 